\title{
The Failure of Democratic Transition in Libya
}

\author{
Naufal Rhyo Ichwanda ${ }^{1}$, Randhi Satria S.IP, M.A ${ }^{2}$ \\ ${ }^{I}$ Student of International Relations Department, Faculty of Social and Political Sciences, Sebelas Maret University. Jl Ir Sutami \\ No 36A, Surakarta, Indonesia. \\ ${ }^{2}$ Department of International Relations, Faculty of Social and Political Sciences, Sebelas Maret University. Jl Ir Sutami No 36A, \\ Surakarta, Indonesia. \\ naufalrhyo@gmail.com,ransatria@staff.uns.ac.id
}

Keywords: Libya, failure, state, democratic, transition

\begin{abstract}
The Libya Revolution in 2011 believed as a progress for democracy in Libya. However, after the revolution, the situation did not get any better and worsened by chaos in Libya. It is already almost seven years from the revolution and there still no clear future of Libya. The civil war and split government made international society questioning what is really happening in Libya after the revolution that believed as a new fresh start for Libya. This paper used explanatory qualitative research method to answer the question "why the democratic transition is failed in Libya?" To answer the question this paper will use state building components theory. This research believes that the failure of democratic transition in Libya is caused by the missing of the state building components.
\end{abstract}

\section{INTRODUCTION}

The revolution in Libya started after the uprising in their neighboring country. The first revolution started in Tunisia in December 2010 then followed by Egypt in January 2011 and Libya in the next month (Smith, 2016). Unlike the other country, the revolution in Libya escalated from people protest into armed conflict between the opposition and the government regime after the government of Libya tried to oppress the people protest with armed violence. National Transitional Congress (NTC) emerged as the main opposition along some local insurgencies or militias against the government (Smith, 2016). With support from North Atlantic Treaty Organization, the opposition can overcome the government forces after 8 months of fighting until the final act when the opposition killed Gaddafi in Sirte and marked the victory of the opposition (Smith, 2016).

NTC takes the role as internationally recognized replacement of Libya's government (Agarwal,
2013). Following the end of the war, the NTC serves as a temporary government until a parliamentary election held in July 2012 (Agarwal, 2013). After the election, the NTC give the government mandate to the newly formed parliament, General National Congress (GNC) to appoint a prime minister and a cabinet to govern the state of Libya and also creating a new constitution for Libya to replace the old constitution which is a legacy of Gaddafi regime (Agarwal, 2013). However, the transitional government under GNC failed to draft a new constitution (Apap. 2015). The constitution still finished until the formation of House of Representative (HoR) which task is to replace GNC and continue GNC task on 2014 (Apap, 2015). After the election of HoR, the GNC refused to transfer its power to this newly elected parliament. They believed this new parliament is unconstitutional and appealed the results of the election to the court (Apap, 2015). Consequently, Libya government was split up with GNC choosing an office in Tripoli and HoR choosing their office in Tobruk in Eastern 
Libya. International world preferred to recognize the HoR rather than the GNC (Toaldo and Fitzgerald, 2018).

This situation was worsened by a civil war sparkled in the middle of the transition. A former general in Gaddafi era, Khalifa Haftar, proclaimed himself as leader of Libya Nationals Army (LNA) and launched an operation called Operation Dignity to battle the Islamist Militia in Libya, especially those who have the link with the international terrorism organization, and declared their support for the HoR as the legitimate government (Apap, 2015). LNA also supported by some tribal and nationalist militia in Libya (Apap, 2015). Meanwhile, the militia under GNC also fights back Operation Dignity by launching its own operation called Operation Dawn. Militia forces support under GNC mainly consisted from Libya Dawn and Libya Shield that were taking the role of the armed forces of the GNC. Besides those two factions, the support also came from another smaller group and led under the command of GNC's member Nuri Abu Sahmain (BBC, 2016).

United Nations (UN) then tried to resolve the situation in Libya by creating an agreement to form a new government in December 2015 (Toaldo and Fitzgerald, 2018). This agreement is made to form a unity government to replace the dual government under the provision of UN. This new government is the internationally recognized government replacing the HoR and was temporarily run by Presidency Council that consisted of HoR member and led by Fayez Al Sarajj until the election of General National Accord (GNA) after the signing of the agreement from both parties (International Crisis Group, 2016). After the dissolution of GNC in 2016, they formed High Council of the state to replace the GNC as the agreement mandate (Toaldo and Fitzgerald, 2018). But the HoR resigned from the agreement with General Haftar statement in late 2017 (al-Warfalli, 2017).

This terrible situation made up Libya to be divided into two major territories. Eastern Libya with capital of Tobruk was being ruled by HoR and Khalifa Haftar forces, the Libyan Nation Army (International Crisis Group, 2016). The UN also backed government and internationally recognized government, GNA, which now holds the western part of Libya after the dissolution of GNC and absorbent of GNC former territories to GNA
(Toaldo and Fitzgerald, 2018). With the territorial partition between those parties, it makes the future of this state unclear.

The conflicts in Libya indicated government's struggle to consolidate the power after the revolution. It is clear that democratization process is not enough to solve Libya's problem. More than seven years of democracy era, Libya is still unstable and had many problems to be resolved. The democratization could be considered as fail. Nonetheless, the reasons behind this failure should be found, whether it is because the democracy itself or because there is something wrong with Libya itself. It seems that something had been hindering Libya to apply the democracy to their country.

\section{METHODS}

\subsection{Explanatory Qualitative Method}

This paper explains with explanatory qualitative method by seeks the reasons behind the problem rather than give answer to describe what happens and also looks for a way to a more comprehensive understanding of the problem case (Elman, 2005). This method needs an existing theory to be applied and seeks the relationship between the two (Elman, 2015). The purpose of this method is to find out and explain the correlation between the factors and the study case (Elman, 2005).

\subsection{State Building Components}

Barry Buzan in his book "People, States, and Fear", proposes three concepts which become the main components of a state. Those concepts are the idea of the state, institution of the states, and physical base of the state (Buzan, 1983). They are the main requirements to be fulfilled before building a state and the presence of those concepts are strong factors that keep a state still exist although many things have threatened the security of a state.

The idea of the state is a concept of something that binds society together to form a state and willing to operate it (Buzan, 1983). The concept can be shared ideology among people inside the states or common consensus between them then this can hold 
many components together. If this component is weak, it needs a strong force to replace it (Buzan, 1993). The absence of this element and the force to replace will make a country struggle for their existence. The absence of the other element to support will only create a nation (Buzan, 1993)

The next is the institution of the state that is some governance institutions that organize the state, then the state could be operated rightly, shortly institution of state is the government of state (Buzan, 1983). In a state building process, if there is already an old institution, it needs to be destroyed or modified before creating the new one (Buzan, 1983). A strong institution of the state can be the force to replace idea of the state to hold people together (Buzan, 1993). Strong institution can force their power to their people if there is no idea of the state or weak idea of the state then the people will follow the institution such as what happen in authoritarian country (Buzan, 1983). A weak institution often indicates by its instability and lack of support from people (Buzan, 1993).

The last is the physical base of the state. It is all states factors that visible in the real world such as territory and people (Buzan, 1983). This element is the easiest to define because of their existence that element represents of state in reality. Without this element, the state will only be an imaginary thing or just a future plan.

\subsection{State and Democratisation}

This theory proposed by Giovanni Carbone in 2015 in his paper regarding state building and democratization. He argued that state is a basic precondition element that must be established first before entering the democratization (Carbone, 2015). He explained that at least basic form of state that consisted of three major elements has to be existed prior to the application of democracy (Carbone, 2015). Those three elements are basically explained of Barry Buzan's idea of institution of a state. These three elements are the establishment of political order, the presence of administration, and legitimacy over the citizen of the state. Democracy is a form of authority limitation by the citizen, but before it is established. It requires the establishment of the authority first (Carbone, 2015).

\section{RESULT AND DISCUSSION}

The 2011 Libyan Revolution was praised as a big democracy progress that even takes bloody violence in order to establish democracy. The success of the revolution provided more room for democracy activities such as political expression and election. One of the progress marks was the presence of the first Libya election in 2012 (BBC, 2012). Libya under 42 years dictatorship of Gaddafi was using an ideology of Jamihiriyah or states of masses which resulted a small group of people acted as the representative of the people to give the state direction (Kafala, 2011). This representative was chosen by Gaddafi and made him so powerful (Kafala, 2011).

After the first election and formation of the new government, the struggle of the transitional government started to appear. Their failure to reach any agreement between themselves showed that there were conflicts of interest inside the new government that cannot be reconciled. The impact of this government failure towards citizens could be seen in the second election. The first election had 2.9 million eligible voters with $62 \%$ of them used their voting rights (BBC, 2012). Meanwhile, the second election in 2014, the number of eligible voters fell to 1.5 million and only $42 \%$ of them used their voting rights (Elumami \& al-Warfalli, 2014). One of the reasons behind the declining amount of voters was because of the upset of people towards the parliament. The GNC also believed to be responsible for more chaos in Libya and reducing the support from people of Libya (Jawad, 2014).

\subsection{Democratic Transition and State Building Components}

Libya Revolution process somehow eliminated the previous state condition and created chaos after the revolution because the revolution was lack of components that required to builds a state. Formally, the power and state institution was transferred from the Gaddafi government into the transitional government. According to Carbone (2015), democracy in Libya actually was hard to be applied since the authority did not really hold the power.

The first state component that absents is the idea of the state. Libya's idea of the state was replaced by 
fear when Gaddafi ruled. The fear was applied in the form of oppression from government towards any political activities. Libya under Gaddafi era also suppressed any ideology besides Jammihiriyah. The emergence of 200 political entities with various ideologies after the fall of Gaddafi reflected how diverse Libya politics actually are (BBC, 2012). During the revolution, Libyan people were having a shared idea that tied them together and made people to overthrow Gaddafi. However, after the revolution, there was no more shared ideas between them. Militias often fight each other, deadlock discussion in the parliament and the peak was the split between Libya governments in 2014. UN also failed to recognize or create any ideas of the state in Libya. The plan to unify Libya had been considered fail after the resignation of General Haftar and its alliance with the HoR from the UN agreement in late 2017. The resignation of one party in the agreement indicated that there was still no consensus reached between them.

Moreover, Libya is separated geographically into three major regions which are Tripolitania, Cyrenaica, and Fezzan. Tripolitania is the region in the northwest of Libya including the city of Tripoli, Cyrenaica is the region in the northeast of Libya including the city of Benghazi, and Fezzan is in the south of Libya. Demographically, people in Tripolitania are more related to the Maghreb region which is including Tunisia, Algeria, and Morocco. Meanwhile, Cyrenaica region is more related to Mashriq region which includes Egypt. Meanwhile, Fezzan region is neither Maghreb or Mashriq and closer to northern Chad and Mali (Harmon, 2014). From the demography of the regions, it can be concluded that Libya has three major regions with their different necessity, demands also perspective to approach the idea of Libya state. A unifying idea is urgently required by Libya to unite their people. The idea should be as strong as the anti-Gaddafi sentiment back in 2011 revolution era which could unite almost all Libya citizens regardless of their region or their ideology.

The absence of idea of the state affected to the absence or weakness of another element. The most affected element is the institution of the state since the institution of state needs ideas of state as a legitimation over the people. When the Gaddafi ruled, he created a strong institution with strong coercion force in order to ensure his regime will operated correctly (Buzan, 1993). Therefore, after the fall of Gaddafi, Libya lost its strength on institution of state since they lost their coercion forces and do not have any idea of the state. They started to build again their institution from the scratch. They tried to build a parliament, meanwhile only small of them ever experienced representative democracy. As the result, their inexperience and their absence of unifying ideas resulted they cannot compromise each other ideas which can be seemed in their failure of creating a new constitution.

Another weakness of Libya state institution is the government stability, one indicator of state institution strength (Buzan, 1993). Short time duration of each internationally recognized government resulted instability in domestic politics. In seven years, there are already four internationally recognized governments with average governing time around one point seventy-five years or around twenty-one months. They lacked of time to build and consolidate each other's interest. The split of government inside Libya also worsened this element. The GNA only hold the western part of Libya and the rest is under General Haftar and HoR alliances. This division created difficulty for the GNA, the internationally recognized government cannot apply their law and order in General Haftar territories since they are not in control of the territories. At the past, the split of Libya's government was mainly caused by the refusal to transfer power from the old one to the new one. A weak institution often does not have a smooth transfer of power since they are did not have general support from the people.

Another hint that indicated the weakness of institutions of the state in Libya is the failure of Libya government to consolidate militia forces in Libya. The existence of militias is a result of the unfinished revolution in Libya. Militias were originating from the opposing army to fight Gadaffi loyalist army. The government should absorb or disbanded them to prevent another chaos. Disbanding them is hard because they are more equipped that is supplied by NATO and they bought from black market. Thus, it would risk armed conflict if the militias disagree to be disbanded. General Haftar and his LNA tried to disband some of them through armed fight and the result is the civil war from 2014 until now. It is hard to absorb 
them since they have their own ideology that is often different from the ruling government.

The government prefers to use them as complimentary to the regular forces by subsidizing them since they are well equipped too (Wehrey, 2014). This action was called as the hybrid theory, where the government uses a mix of professional army and informal army as their official forces (Wehrey, 2014). This tactic is a result of the weak institution in Libya that caused the government cannot gain trust from militias to join their official forces. Giving the militia trust to be government official forces will give them legitimation to do things they are not supposed to do for their own benefit such as security taxes.

The high presence of militia or armed forces across Libya territories and the split of Libya government reduce the legitimacy which is one of the basic requirement of a state (Carbone, 2015). The current government of Libya clearly fails to accomplish this, because they did not have any legitimacy over armed forces. Furthermore, the split of Libya prevented each other to extend their legitimacy all over Libya and one of them must transfer their territory or a Libya state will not be realized.

The uncertainty government of Libya in resolving those two weak or missing elements created chaotic situation. It will still exist and democracy will be hard to be applied. Even, the election that will be held on 2018 is highly in doubt that will create another solution to Libya. If we reflect on the past events, a forced transition of power which is in form of election will emerge another problem such as what happened in 2014. Although the General Haftar side and GNA side has agreed to hold an election on 10 December 2018 (Reuters, 2018). They still need to define their idea of state or otherwise the election will be a momentary shared idea just like the vision to overthrow Gaddafi in 2011. After the moment, they will lose their shared ideas and contest each own interest.

Each government needs to clear their basic administration and political order first before moving into democracy. The example could be illustrated simply by managing the citizens and armed forces inside each territory. Disbanding or absorbing local armed forces could increase legitimacy over some region and citizens who live in that region. Each government must give their time to clear their own problem before uniting into one. From the experience, a short time given to the government will create a new problem in the end.

They need to seek their idea that is able to unite them, such as the political system, the ideology, their purpose for the state, and others as long as each party inside Libya agreed. These two governments have their own idea and refusing to compromise with each other. The unity of two rivaling government would be a big progress towards the rebuilding process of Libya.

If needed, coercive forces such as foreign forces or dictator power could be used to bond Libya together for a while. This action may be chosen if it necessary just in order to establish the state function. Coercive forces may result another armed conflict from parties that refusing to be under the rule of the coercive forces and worsening the situation. Foreign forces clearly have been failed to fulfill the demand of Libya people. The GNA was mediated by the UN rejected by some of Libyan especially the HoR side. Foreign forces still need to answers the demand of all side in Libya first if they want to enter Libya peacefully.

The presence of a unifying idea of the states likely will clear the path to finish the transition of Libya. However, it must be followed or preceded by the state institution because if the state institution still not reformed although the idea of the state has been founded. The missing of the state institution will create them into like a stateless nation like the Kurds (Buzan, 1983).

\section{CONCLUSION}

The democratic transition in Libya carried hope to have a better condition for the people but the democratic transition missed the state condition required before applying the democracy that resulted failure in the state-building or state-maintaining process. State components that essential for building a state or defending a state from any threats in Libya was missing under Gaddafi era and revolution era. It can be reflected after the first election in Libya and still unresolved until now.

The idea of the state that had been lost rule inflicted serious effect on the work of Libya 
government after the Gaddafi regime. At first, they had failed to identify the shared ideas or common consensus among Libyan people. Their failure in this phase resulted in the loss of general supports for government which made difficulties in consolidating power and in the transfer of power process. This difficulty created a split government and sparked the civil war that still exists until now. Furthermore, the absence of the idea of the state worsened by the collapse of the strong institution under Gaddafi regime and replaced with a weaker and newer one. A weak institution is unable to extent their power over object that actually under it. The example in Libya is how the government failed to manage the militias.

The loss of two elements above is very crucial for Libya's condition to rebuild their state again. The democratization that has been tried to be applied facing big failure ahead if the government does not recognize it until now. Libya will stay under chaos until the uncertain time, and it will likely follow the path of Somalia to be one of a failed state in the world. Any democratization attempt will be useless if they fail to fulfill the state components that are mentioned first. Thus, democratization is actually still far to be realized in Libya. Although it has been practically applied since 2012 , the democratization needs to wait for a little longer time. The reality of Libya condition cannot be avoided, and it must be repaired first than ignoring the condition.

\section{REFERENCES}

Smith, L, 2016, "Arab Spring 5 years on: Timeline of the major events and uprising in the Middle East", International Bussines Times, 25 January. Viewed on 23 May 2018, <https://www.ibtimes.co.uk/arab-spring-5-years-timelinemajor-events-uprisings-middle-east-1539085>

Agarwal, R, 2013, "Libya: A Case of Revolution Gone Awry?", Institutes for Defence Studies and Analyses, June, viewed 24 May 2018, <https://idsa.in/africatrends/libya-a-case-ofrevolution-gone-awry_0613>

Apap, J, 2017, "Political development in Libya and prospect of stability”, European Parliamentary Research Services, June, viewed 23 May 2018 $<$ https://www.google.co.id/url?sa=t\&source=web\&rct=j\&url $=\mathrm{http}: / / \mathrm{www}$.europarl.europa.eu/RegData/etudes/BRIE/2017/ 603959/EPRS_BRI(2017)603959_EN.pdf\&ved=2ahUKEwij 24KjhKzbAhXMbSsKHZFqCMwQFjADegQIBRAB\&usg= AOvVaw1ECfE-CQGiKlu3dYs_wtDL>

Toaldo, M \& Fitzgerald, M, 2018, "A Quick Guide to Libya's Main Players". European Council on Foreign Relations, viewed $24 \quad$ May 2018, <http://www.ecfr.eu/mena/mapping_libya_conflict>

International Crisis Group, 2016, "The Libyan Politival Agreement: Time for a Reset", International Crisis Group, 4 November, viewed 23 May 2018 $<$ https://www.crisisgroup.org/file/3848/download?token=gvC dqvfo>

BBC, 2016, "Guide to key Libyan militias", $B B C, 11$ January, viewed on 24 May $2018<\mathrm{http} / / / w w w . b b c . c o . u k /$ news/worldmiddle-east-19744533>

Al-Warfalli, A, 2017, "East Libyan Commancder Haftar Says U.N.-backed governent obsolete, hints may run in elections", Reuters, 17 December, viewed 24 May 2018, <https://www.reuters.com/article/us-libya-security/eastlibyan-commander-haftar-says-u-n-backed-governmentobsolete-hints-may-run-in-elections-idUSKBN1EB0FB>

Wehrey, F, 2014, "Ending Libya's Civil War: Reconcilng Politics, Rebuilding Security", Carnegie Endowment for International Peace, 24 September, viewed, 23 May 2018, <https://carnegieendowment.org/2014/09/24/ending-libya-scivil-war-reconciling-politics-rebuilding-security-pub56741>

Buzan, B, 1983, People State \& Fear, Wheatsheaf Books Ltd, Sussex,

BBC, 2012, "High turnout in historic vote", BBC News, 7 July, viewed 25 May 2018. <http://www.bbc.co.uk/news/worldafrica-18749808>

Kafala, T, 2011, "Gaddafi's quixotic and brutal rule", BBC News, 20 October, viewed 25 May $2018 . \quad<$ http://www.bbc.co.uk/news/world-africa-12532929>

Elman, C, 2005, "Explanatory Typologies in Qualitative Studies of International Politics". International Organization vol 59 no 2 pp 293-326, viewed 28 May 2018, Researchgate database DOI 10.1017/S0020818305050101

Jawad, R, 2014, "Libyan elections: Low turnout marks bid to end political crisis", BBC News, 26 June, viewed 25 May 2018 <http://www.bbc.co.uk/news/world-africa-28005801>

Elumami, A \& al-Warfalli, A, 2014, "Poor turnout in Libyan parliament vote as prominent lawyer killed", 25 June, viewed 27 May $2018<$ <ttps://www.reuters.com/article/us-libyaelection/poor-turnout-in-libyan-parliament-vote-asprominent-lawyer-killed-idUSKBNOF000720140626>

Wintour, P, 2018, "Libyan factions agree to holf elections on 10 December", The Guardian, 29 May, viewed 29 May 2018 , <https://www.theguardian.com/world/2018/may/29/macronhosts-libyan-factions-in-paris-in-push-to-secure-elections >

Carbone, G. 2015. "Democratisation as a State-Building Mechanism: A Preliminary Discussion of an Understudied Relationship" Political Studies Review Vol. 13, pp 11-21 Viewed 10 August 2018 Political Studies Association doi: 10.1111/1478-9302.12020

Harmon, D. 2014. Libya. Simon and Schuster. New York City 